gases such as ozone and water vapour, as well as of the intensities of the radiations coming from the sun and earth. During the discussion which followed, Dr. L. Jánossy pointed out that the tropopause falls rapidly at the same latitude that shows a marked increase in cosmic ray intensity. Cosmic rays might conceivably produce some ozone, and so account for the higher temperatures over the poles.

\section{Recent Earthquakes}

The United States Coast and Geodetic Survey, in co-operation with Science Service and the Jesuit Seismological Association, has determined the epicentres of two recent earthquakes. The first was on September 26, 1942, and took place at approximately 4h. $00 \cdot 3 \mathrm{~m}$. U.T. It had an epicentre near lat. $12 \cdot 8^{\circ} \mathrm{N}$., long. $87.5^{\circ} \mathrm{W}$., which is in the region south of the Golfo de Fonseca in Nicaragua in Central America. The second occurred on October 21, 1942, at about 16h. $22 \mathrm{~m}$. 15s. U.T. and had an epicentre near lat. $33 \cdot 1^{\circ} \mathrm{N}$., long. $116 \cdot 0^{\circ} \mathrm{W}$., which is to the west-northwest of Imperial in Southern California.

That the earth blocks, the movement of which caused the very severe earthquake of December 27, 1939 in Anatolia, have not yet attained their position of equilibrium is shown by the earthquakes and tremors which still occur in the district. The latest strong shock of this series occurred about 10 p.m. local time on December 3. At Ciorum, sixty miles from Ankara, the tremors lasted 25 seconds according to human perception. Four people are reported to have lost their lives and nine were injured in Central Anatolia.

\section{Sir William Power, F.R.S. (1842-1916)}

Sir Wruliam Henry Powkr, an eminent Victorian epidemiologist, was born at Bosworth on December 15, 1842, the son of a medical practitioner. $\mathrm{He}$ was educated at University College, London, and qualified in 1864. After serving as resident medical officer at the Victoria Hospital for Diseases of the Chest, where he gained much valuable information in connexion with tuberculosis, he was appointed in 1871 temporary medical inspector in the Local Government Board, where he made a special study of the small-pox epidemics in London of 1871-72 and 1881 and upheld the theory of the aerial convection of disease, particularly in relation to the Western Hospital, then known as the Fulham Small-Pox Hospital. The publication of his "Statistics of Small-pox Incidence in the Registration Districts of London relating to the Operation of Small-pox Hospitals in the Metropolis" led to the permanent removal of all small-pox cases occurring in London to extra-metropolitan hospitals, a practice which still holds good. His other publications included reports on epidemics of diphtheria in Warwickshire and Essex, an outbreak of scarlet fever in certain districts of London believed to be due to milk, and lead poisoning by public water supplies. In 1871 he was appointed assistant medical officer in the Local Government Board, and in 1889 succeeded Sir Richard Thorne Thorne as senior medical officer, when he did valuable work in connexion with the Food and Drugs Aets and the Royal Commission on Tuberculosis. In 1895 he was elected a fellow of the Royal Society. He was also awarded the Jenner Medal of the Epidemiological Society of London, the Bissett-Hawkins Medal of the Royal College of Physicians and the Stewart Prize of the British Medieal Association. He died on July 28, 1916.

\section{Marius Sophia Lie (1842-1899)}

ON December 17 occurs the centenary of the birth of the distinguished Norwegian mathematician Marius Sophia Lie, who was born at Nordfjordeif, near Bergen. Educated at the University of Christiania (Oslo), he took his doctonate in 1868 and, after gaining a travelling scholarship, visited France and Germany, making the acquaintance of Klein, Darboux and Jordan. In 1872 a special chair of mathematics was created for him at Christiania, but fourteen years later he returned to Germany to succeed Klein at Leipzig. He returned to the Norwegian capital in 1898 , and died there on February 18, 1899. Lie was recognized as one of the most original and independent workers in pure mathematics; he was elected a foreign member of the Royal Society, and the Cambridge Philosophical Society and the London Mathematical Society added his name to their lists of honorary members. Referring to his death, Larmor said, at the meeting of the British Association in 1900, "We have lost one of the greatest constructive mathematicians of this century, who has in various directions fundamentally expanded the methods and conceptions of analysis by reverting to the fountain of direct geometrical intuition".

\section{Admiralty Appointments}

THE appointment is announced of Commander C. F. Goodeve, F.R.S., R.N.V.R., reader in physical chemistry at University College, University of London, to the post of assistant controller (research and development) in the Admiralty. Commander Goodeve will be responsible for the co-ordination of research and development in the departments of the Controller of the Navy, and for ensuring that scientific opinion is adequately represented in those Departments and that due weight is given to it.

Sir Stanley V. Goodall, director of naval construction, has been given the additional appointment of assistant controller for warship production. $\mathrm{He}$ will remain the principal technical adviser to the Board of Admiralty on the design of warships and other vessels for the Royal Navy. In his capacity as assistant controller for warship production he will be responsible under the Controller of the Navy for the produc. tion of warships and their completion with all appropriate supplies, and for the necessary co-ordination to achieve the fastest possible results with the greatest economy of effort.

\section{Announcements}

Sir John Russell retires on September 30, 1943, under the age limit, from the directorship of the Rothamsted Experimental Station. Sir John Russell succeeded Sir Daniel Hall in 1912 and during his thirty-one years as director the Station, the oldest agricultural institute in the world, has shown a remarkable expansion of its research activities and of its authority in agriculture.

Mr. Harry R. Ricardo, who is well known for his outstanding work in connexion with internal combustion engines, has been elected an honorary member of the American Society of Mechanical Engineers, New York.

IN recognition of his distinguished services as rector of the Imperial College of Science and Technology during 1929-42, Sir Henry Tizard, president of Magdalen College, Oxford, has been elected a fellow of the Imperial College. 